\title{
Geographic information systems based demarcation of risk zones: the case of the Limbe Sub-Division - Cameroon
}

\author{
Buh Wung Gaston \\ GIS/RS Officer \\ Limbe Botanic Garden, Cameroon \\ buhgaston@yahoo.com
}

\section{ABSTRACT}

In the Limbe Subdivision of Cameroon, landslides and flooding are frequent threats. The worst recorded event occurred in June 2001, when floods and landslides took the lives of some 30 persons, left over 2000 people homeless, and destroyed property and social amenities including roads and telephone lines worth hundred of thousands of US Dollars. The objective of this project was to assist local administrative officers, other decision makers and planners to understand which areas to concentrate their efforts on in order to develop mitigation actions to protect the lives of the population in these zones that are affected by flooding and associated landslides. To meet this objective the project made extensive use of geospatial tools and existing digital spatial datasets. Series of field data collection exercises constituted an integral part of the project. The project focused on the Limbe subdivision in the south-western part of Cameroon. Areas with high (greater than $60 \%$ ) probability of sliding to occur, occupy $23 \%$ while areas with medium (greater than $40 \%$ and less than $60 \%$ ) probability of sliding to occur occupy $44 \%$ and areas with low (less than 40\%) probability of sliding occupy 33\%. Settlements along the Atlantic coast all lie less than $-50 \mathrm{~m}$ above sea level. These settlements (villages) are susceptible to flooding. Again settlements in the town of Llimbe along the Djenguele river, i.e., Animal Farms, Cassava Farms, Lumpsum areas, Church Street, New Town and Down Beach, are more susceptible to inundation during raining periods and therefore have experienced persistent flooding over the years. 


\section{KEYWORDS}

landslide, flood, GIS, Cameroon

\section{Background}

Most of the geologically related hazards in Cameroon are linked to the existence of the Cameroon Volcanic Line (CVL). Such hazards include toxic gas emissions from volcanic crater lakes, landslides, floods, and hazards related to volcanic eruptions. There are more than 35 crater lakes that occur in association with basaltic cinder cones, scoria and lava flow fields along the continental sector of the CVL (Ateba and Ntepe, 1997). In the last century and early this century Cameroon recorded a series of natural disasters that were identified to be located within and around the corridors of the CVL (Tchoua et al, 2001). These disasters include: The Lake Manoun toxic gas disaster in which 37 people were killed (1984), the Lake Nyos toxic gas disaster, which claimed some 1700-2000 lives (1986) (Kusakabe et al, 1989), the Bafaka Balue Landslide with 3 lives lost (1995) (Ayonghe et al, 1999), the Mount Cameroon (MC) volcanic eruption where lava consumed an enormous amount of forest (about 800 hectares) with its rich biodiversity and cut-off 83 metres of tarred road which disrupted economic activities (1999) (Suh et al, 2003).

Table 1: Reported landslide casualties in Cameroon since 1988

\begin{tabular}{|l|l|l|c|}
\hline Locality & Local Geology & Date & $\begin{array}{c}\text { No. of } \\
\text { fatalities }\end{array}$ \\
\hline Bakombo(Melong) & Volcanics & June 1988 & 8 \\
\hline Oyamabang(Yaounde) & Migmatites & August 1990 & 5 \\
\hline Pinyin(Santa) & Volcanics & September 1992 & 12 \\
\hline Bafaka Balue(Ndian) & Volcanics and sedimentatary & September 1995 & 3 \\
\hline Sho,Belo & Volcanics & September 1997 & 2 \\
\hline Guoata(Dschang) & Volcanics and granites & September 1997 & 1 \\
\hline Baingoh, Belo & Volcanics & July 1998 & 5 \\
\hline Anjin, Belo & Volcanics & September 1998 & 2 \\
\hline Ron(Nwa) & Volcanics and Migmatites & September2001 & 6 \\
\hline Limbe ${ }^{1}$ & Volcanics & June 2001 & 24 \\
\hline Wabane ${ }^{2}$ & Volcanics and granites & July 2003 & 20 \\
\hline
\end{tabular}

$1=$ Gaston(For this article) $; 2=\mathrm{Aka}(2001)$. The rest from Ayonghe et al. (1999) 
Landslide and flood disasters are a common problem in Cameroon. Ayonghe et al.'s (1999) historical statistics on recorded landslides in Cameroon enabled us to estimate that since 1988 at least five people were killed in Cameroon every year from landslide hazards with a huge effect on infrastructure and the economy in general (Table 1). Landslides and floods are therefore among the major human life claimers in Cameroon that warrant an understanding of areas prone to this disaster (Zogning, A., 2001), its causes and the proposed mitigation steps.

\section{Project location}

The Limbe subdivision is a subdivision in the Fako division of the south-west province of Cameroon, located between 3o 90' and 4o 05' $\mathrm{N}$ latitude and 9o 29' and $9006^{\prime} \mathrm{E}$ longitude (Figure1.) This is a coastal region that has approximately $50.5 \mathrm{~km}$ of Atlantic Ocean coastline to the southwest. The subdivision consists of more than 25 villages with an estimated population of 224418 (Neba, 1999) and a surface area of 248.6 square kilometres with the City of Limbe being the capital. It is bordered in the North and North-East by the Buea subdivisions and Tiko subdivisions respectively. It shares boundary to the west with the Idenau subdivision. An equatorial climate prevails which is characterized by a rainy and dry season each year (Ngwa et al., 1987). The rainy season begins in March and ends in October, with rain peaks usually occurring between July and August, having an annual rainfall average of $2000 \mathrm{~mm}$ and peak average rainfall of $3000 \mathrm{~mm}$.

\section{Figure 1: Project Area Location Map}

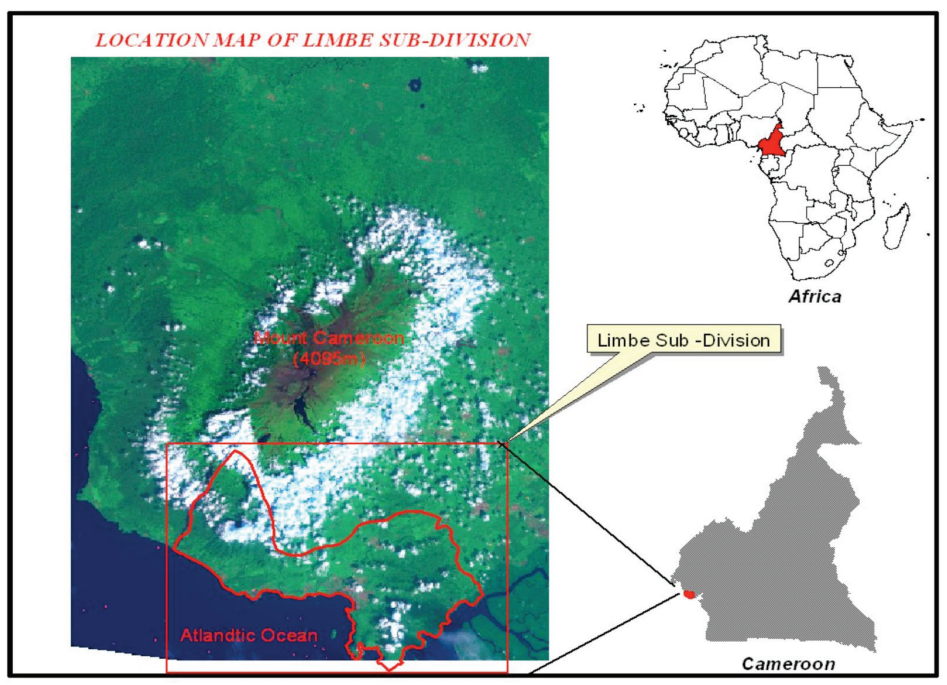




\section{Problem statement}

Over the years, there has been a number of recorded cases of landslides and floods in this region with the worst being the June 2001 disasters that took the lives of some 30 persons, displaced over 2000 others, and destroyed properties and social amenities such as roads, telephone lines worth thousands of US dollars (Aka et al., 2001). Risks related to floods and landslides in this region vary periodically. Moreover, during certain years when the subdivision is considered free from impact caused by floods or landslides, other threats from a Mount Cameroon eruption - particularly lava flows - threaten the population. For effective decision making toward risk reduction in this region, this project focused on the delineation of potential risk zones to enable decision makers and planners to understand areas to concentrate their concerted attempts on in an effort to develop mitigation actions to reduce the level of risk and to guarantee the lives of the population in these zones.

\section{Study Objectives}

The main intention of this project was to provide reliable information that could be useful to decision makers in making informed decisions on effectively and efficiently tackling landslides and floods risk problems in the subdivision. The intention was moreover also to use new approaches in the area of natural disaster preparedness through the use of geospatial tools (GIS, GPS, Remote Sensing) by placing these tools at the disposal of planners which should assist toward risk reduction in this subdivision in accordance with the ProVention consortium in realizing the Hyogo framework (Hyogo Framework for Action, 2005) on Disaster Risk Reduction around the world. The approach therefore aimed at demarcating risk zones through the production of risk zone maps (Espizua \& Bengochea, 2002) of the region showing areas more vulnerable to landslides and floods. Methodology Hardware and software were used for data assembling, interpretation and analysis of imagery to detect, map and verify features. Our initial intention had been to make use of high resolution images or aerial photographs for the execution of this research work rather than using former surveying methods for primary data collection. However, we had to depend on satellite remote sensing from Landsat images, which were the only remotely sensed data available. Extensive use was made of existing feature datasets considering their source, quality, and date of publication. Use was made of Landsat $7 \mathrm{ETM}+$ satellite imagery. (http://www. mdafederal.com/com) They were used for categorizing, interpreting and digitizing features. The 03 time series, medium-to-high resolution (28.5m) orthorectified Landsat TM 7 Enhanced Thematic Mapper (ETM+) 
satellite images sub scene of path186, row 57 of 26/03/1999, 26/04/2001 and $14 / 01 / 2003$ covers 01 scene of the Cameroon Landsat classification scheme. Unfortunately only the April 2003 image was cloud-free and therefore was put to full use for this project. The 1:50,000 topographic maps covering the area corresponding to that of the sub scene were used for features verification. Landsat ETM+ Satellite imagery has a spatial resolution of 28.5 metres per pixel (channels $1-5$ and 7 ) and 14.5 metres per pixel (panchromatic channel) and a view range of $183 \mathrm{~km} \times 170 \mathrm{~km}$.

\section{Image interpretation}

The ETM+ scanner measures the sun's reflectance in seven spectral channels known as bands. These include the visible spectrum (bands 1-3), near infrared (bands 4 and 5), thermal (band 6) and medium infrared (band 7). These bands were selectively combined into colour composite images to enhance visibility. Different band combinations were used to maximize the visibility of landslide scars and different land uses under a range of conditions. The prominent band combinations used included; 7-5-3, 7-5-4, and 5-4-3. To improve the detection of narrow landslide scars and less prominent features, the panchromatic band ( $14.5 \mathrm{~m}$ resolution) was merged with the other bands $(28.5 \mathrm{~m}$ resolution) to create a "pan-sharpened" image. This image enhancement greatly improved the visibility of features before categorization and digitization. Band combinations of 5-3-2 were used to filter out clouds before categorizing.

\section{Topographic Map update}

Topographic map update was performed by image analysis and manipulation. Pixel transformation was carried out by computing the normalized difference vegetative index (NDVI) to improved visual interpretation of enhanced false colour composite (FCC) of the satellite image. NDVI was used for discriminating different vegetations and non-vegetative surfaces. This visual enhancement permitted easy digitization of features on the image.

Different categories were:

1) Non-vegetative areas (settlement, bare ground or outcrop, road)

2) Natural vegetative area (evergreen forest, deciduous forest);

3) Agricultural area (CDC Plantations, farmland etc.);

4) Water surfaces.

Most of the human settlement is around the coast with few villages situated above $200 \mathrm{~m}$. Low-lying areas adjacent to the sea include; Mbojo, Mutowoh, Wovia, 
Ngeme, Man'O War bay, SONARA Bota-Land and a host of other villages in the west coast of the subdivision. Areas around the city of Limbe with remarkable hills include Towel $(362 \mathrm{~m})$, Miletwo $(890 \mathrm{~m})$ Coconut Island (46.5m) Mabetal New layout (295m) Ambas Bay areas (152m), Mount Etindi (>2000m). Over the years the city of Limbe has been experiencing rapid evolution in terms of human population and development and with the construction of an oil refining company in 1978 , the status of the city was raised to a subdivision.

\section{Figure 2: Topographic map update on land use}

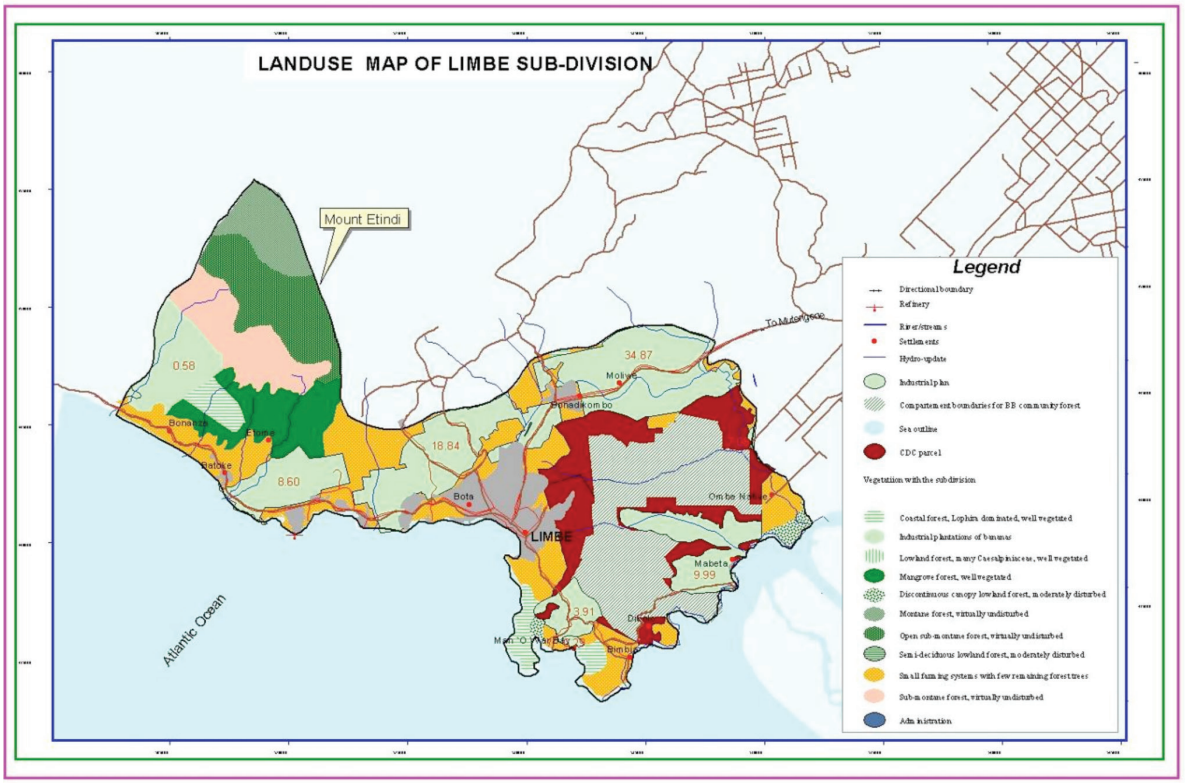

Satellite images were Interpreted and categorized into different spectral classes, using supervised classification for landslide scar and scarp identification . Areas visually interpreted as landslides on the image were marked. Marked portions were later verified in the field with the use of the Global Positioning System. The reason was that the spatial resolution of Landsat 7 ETM+ does not show clear distinctions between ordinary bare ground and landslide scars or scarp (Sigurdsson et al., 1987). During fieldwork, at every locality a series of measurements were carried out to determine volume of material that was displaced by the slide and other attributes about the landslide were recorded. The topographic map also provided useful information about potential landslide zones based on the topographic gradients. 


\section{Figure 3: Landslide risk zones}

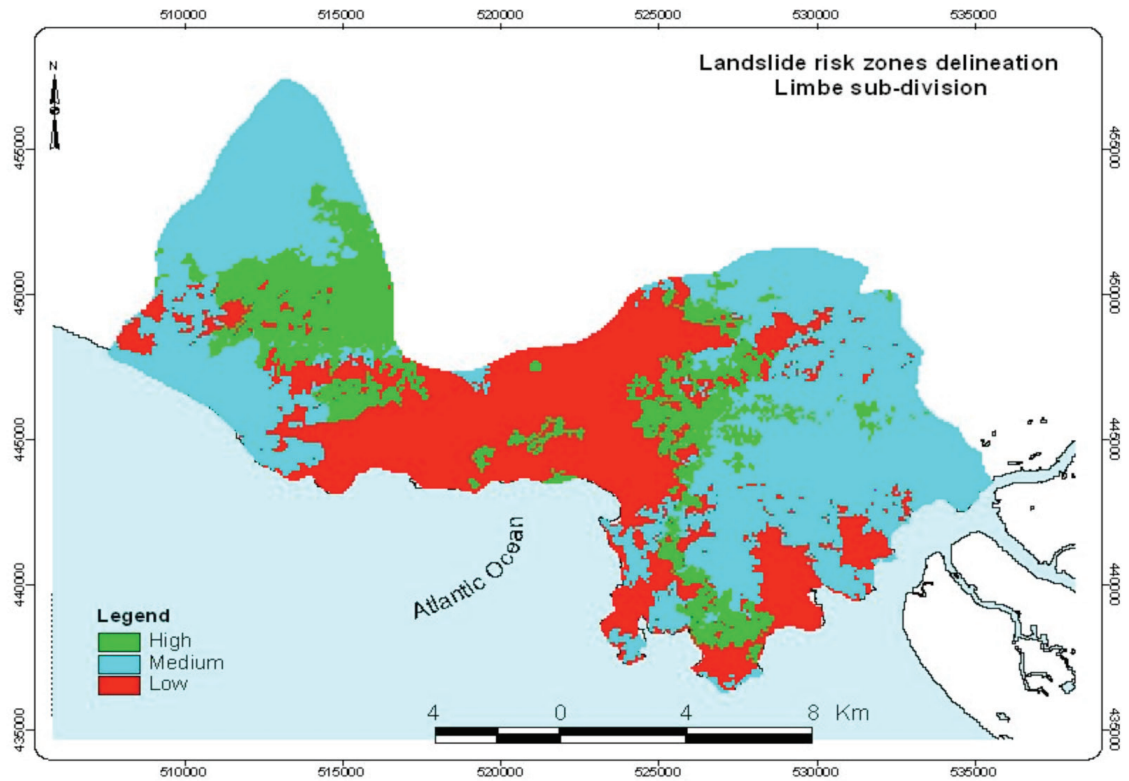

Generally overall results from the statistical computation of the cartographic features of the subdivision showed that landslide hazards zones and areas with high (greater than 60\%) probability of sliding occupy 23\% while areas with medium (greater than $40 \%$ and less than $60 \%$ ) probability of sliding occupy $44 \%$ and areas with low (less than 40\%) probability of sliding occupy 33\%. Most of the high hazard zones are concentrated within the city of Limbe and other built up areas.

Table 2: Landslide parameters around the city of Limbe

\begin{tabular}{|c|c|c|c|c|c|c|c|c|}
\hline \multirow{2}{*}{ Location } & \multirow{2}{*}{$\begin{array}{l}\text { Elevation } \\
\text { (m) }\end{array}$} & \multirow{2}{*}{$\begin{array}{l}\text { Length } \mathrm{L} / \\
\text { (m) }\end{array}$} & \multirow{2}{*}{$\begin{array}{l}\text { Width } \\
\text { W/(m) }\end{array}$} & $\begin{array}{c}\text { Height } \mathrm{H} \\
=\end{array}$ & Area & \multirow{2}{*}{$\begin{array}{l}\text { Volume of material } \\
\text { displaced } \mathrm{V} / \mathrm{m}^{3}\end{array}$} & \multirow{2}{*}{$\begin{array}{c}\text { Slope } \\
\text { Angle/i } \\
\left(^{\circ}\right)\end{array}$} & \multirow{2}{*}{ Slope } \\
\hline & & & & (h-ha) m & $\begin{array}{l}\mathrm{A} / \\
\left(\mathrm{m}^{2}\right)\end{array}$ & & & \\
\hline Mile two & 127 & 13 & 5 & 57 & 65 & 3705 & 77.2 & 4.4 \\
\hline Mabeta Newlayout & 70 & 30 & 12 & 29 & 360 & 10440 & 44 & 0.97 \\
\hline Mabeta Newlayout & 69 & 9 & 5 & 28 & 45 & 1260 & 72.2 & 3.1 \\
\hline MabetaNewLayout & 131 & 26 & 19 & 90 & 494 & 44460 & 73.9 & 3.5 \\
\hline Mawoh & 153 & 25 & 12 & 112 & 300 & 33600 & 77.4 & 4.45 \\
\hline Caterpillar Hill & 41 & 21 & 10 & - & 210 & 0 & - & - \\
\hline Caterpillar Hill & 76 & 25 & 18 & 35 & 450 & 15750 & 54.5 & 1.4 \\
\hline Mbibia road & 63 & 5 & 3 & 22 & 15 & 330 & 77.2 & 4.4 \\
\hline
\end{tabular}

Source: Aka 2001. 
The Mabeta-1 landslide of June 2001 was the biggest and most disastrous landslide. Over $100,000 \mathrm{~m} 3$ of soil turned to mud by rain and ground water was displaced in a quasi North-South direction for some $250 \mathrm{~m}$. From the line of surviving houses on the western side of the scarp, it was noted that furthest up-slope houses were located at about $108 \mathrm{~m}$ altitudes.

\section{Photo 1: Mabeta new layout, landslide, 2001}

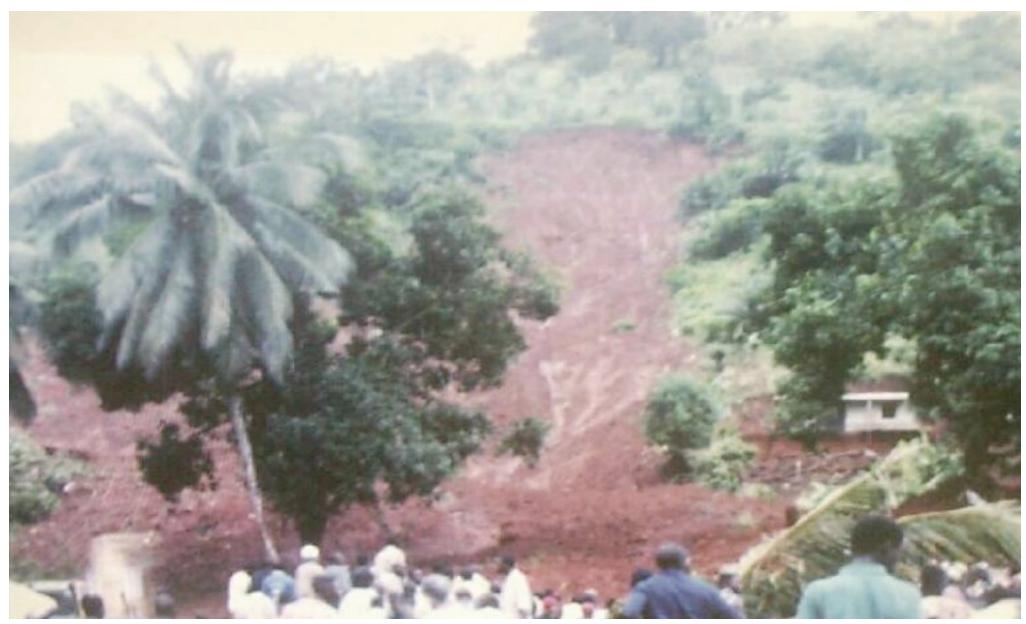

\section{Flood Delineation}

A literature review of the flood history of the area, image interpretation, analysis, and field work have accentuated the delineation of the flood risk zones. Settlements along the Atlantic coast all lie $<50 \mathrm{~m}$ above sea level. These settlements (villages) are susceptible to flooding. The level of vulnerability varies in the different settlements. The city of Limbe has been most hit by the impact of flooding of late, resulting from anthropogenic causes. Since 1999, many quarters within the city of Limbe has been constantly exposed to inundation during the rainy seasons.

Limbe River and Djenguele River drain Limbe. The latter rises from four (4) springs in the steep thick soil-colonized ash and scoria hills to the northeast and crosses the entire city of Limbe $3.5 \mathrm{~km}$ before entering the Atlantic Ocean to the western part of the villages of Ngeme Isokolo, and Krater are drained by a series of Streams and rivers which get their rise from Mount Etindi. Settlements along Djenguele River in other words, Animal Farms, Cassava Farms, Lumpsum areas, Church Street, New Town and Down Beach are more vulnerable to inundation 
Figure 4-I and II: Seasonal flooded areas within the city of Limbe and regularly inundated rivers and streams during raining seasons

(I)

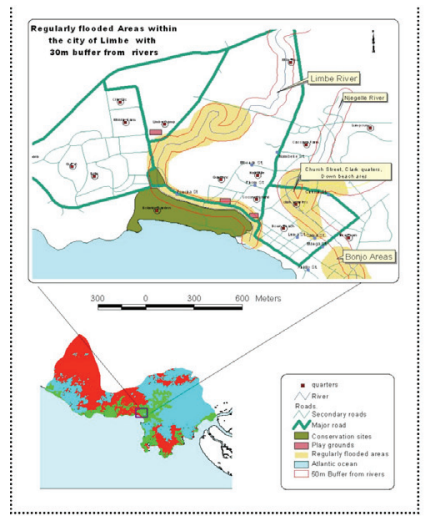

(II)

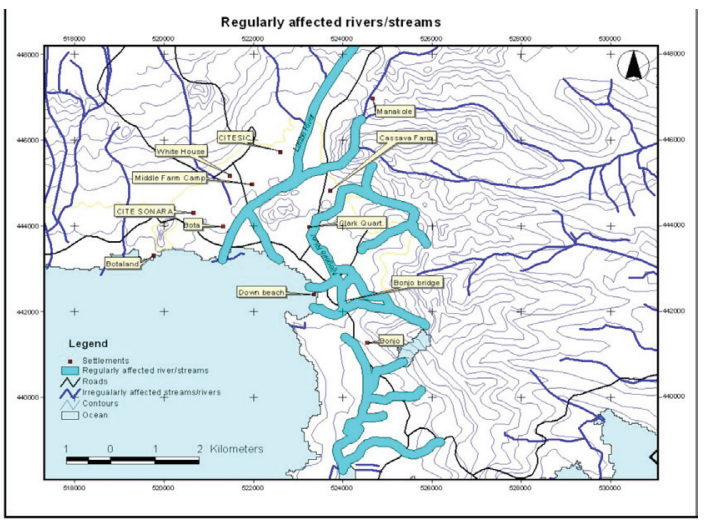

during raining periods and thereby experiences persistent flooding over the years. At Maho bridge $\left(04^{\circ} 00.72^{\prime} \mathrm{N}, 09^{\circ} 13.17^{\prime} \mathrm{E}\right)$, during raining seasons, water usually rise to a height of $2.6 \mathrm{~m}$. The width of the riverbed that was formerly just a small channel has now increased to $27 \mathrm{~m}$ due to series of flood events.

Further downstream, the riverbanks are now more extensive, the floodwaters have spread out and the width reaches $100 \mathrm{~m}$ in some places during raining months. Large boulders, some measuring $1.8 \times 1.3 \times 1 \mathrm{~m}$ torn are brought from the hills, including large tree trunks which dropped because the water current reduced on spreading out in the low- lying flat valley. Though houses are usually destroyed and a lot of property lost. In August 1989, flood caused damage to property but no human casualties were reported (Agingy-personal communication, 2005). Casualties were reported from the floods of June 2001 (At 4o $00.90^{\prime} \mathrm{N}, 9013.89^{\prime} \mathrm{E}$,) up stream, where two small landslides occurred near the head of the natural drainage course into a deep narrow ravine carved through the thick soil mantle down to a compact basaltic lava flow. Tar-marked road collapsed at 2 localities at Down Beach Quarters due to the flood. Close to the Provincial office of Public Works at 4o $00.30^{\prime} \mathrm{N}, 9012.61^{\prime} \mathrm{E}$, about $140 \mathrm{~m} 3$ of tar-marked road was broken (Aka, 2001)

Near Mbonjo Beach Inn junction at 4o $00.19^{\prime} \mathrm{N}$, 9o $12.69^{\prime} \mathrm{E}, 320 \mathrm{~m} 3$ another portion of the same road collapsed. Concrete power supply poles were destroyed. Seawater wave front positions were observed $40 \mathrm{~m}$ from the road along which the broken roads occurred. Houses collapsed and casualties were reported during the 2001 incident in several areas in the city of Limbe. 


\section{Table 3. August 2005 flood observation}

\begin{tabular}{|l|l|l|l|}
\hline \multicolumn{1}{|c|}{ Locality } & \multicolumn{1}{|c|}{$\begin{array}{c}\text { Average height of } \\
\text { flood }\end{array}$} & $\begin{array}{c}\text { Duration of } \\
\text { flood }\end{array}$ & \multicolumn{1}{|c|}{ Observation } \\
\hline Lumpson & $80 \mathrm{~cm}$ & $2 \mathrm{hrs}$ & Most severe \\
\hline Lower Cassava & $90 \mathrm{~cm}$ & $5 \mathrm{hrs}$ & Very severe \\
\hline Mile two & $40 \mathrm{~cm}$ & $3 \mathrm{hrs}$ & Severe \\
\hline Church street & $40 \mathrm{~cm}$ & $5 \mathrm{hrs}$ & Less severe \\
\hline New Town & $75 \mathrm{~cm}$ & $5 \mathrm{hrs}, 30 \mathrm{mins}$ & Very severe \\
\hline Manga William's & $60 \mathrm{~cm}$ & $6 \mathrm{hrs}$ & Severe \\
\hline Clerk's Quarter & $95 \mathrm{~cm}$ & $7 \mathrm{hrs}$ & Most severe \\
\hline Bonjo/ Down Beach & $80 \mathrm{~cm}$ & $7 \mathrm{hrs}$ & Severe \\
\hline
\end{tabular}

\section{Photo 2: Flood-effect collapsed portion of tarred road in Limbe}

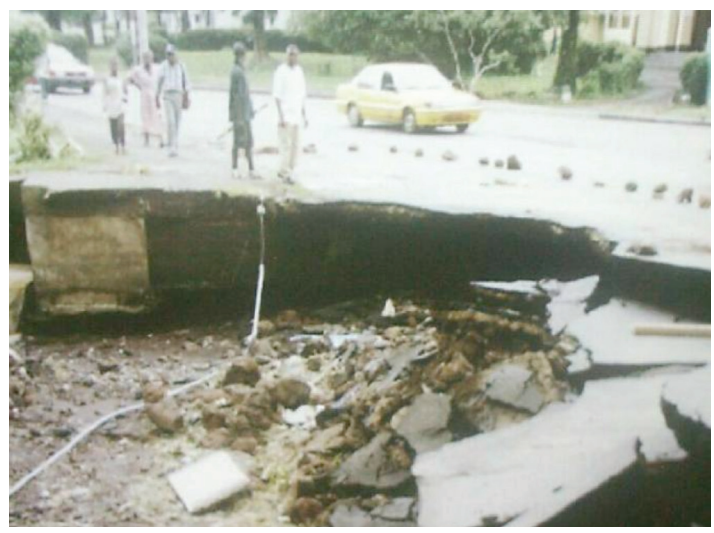

\section{Photo 3: Flood-effect destroy streams nearby houses in Limbe}

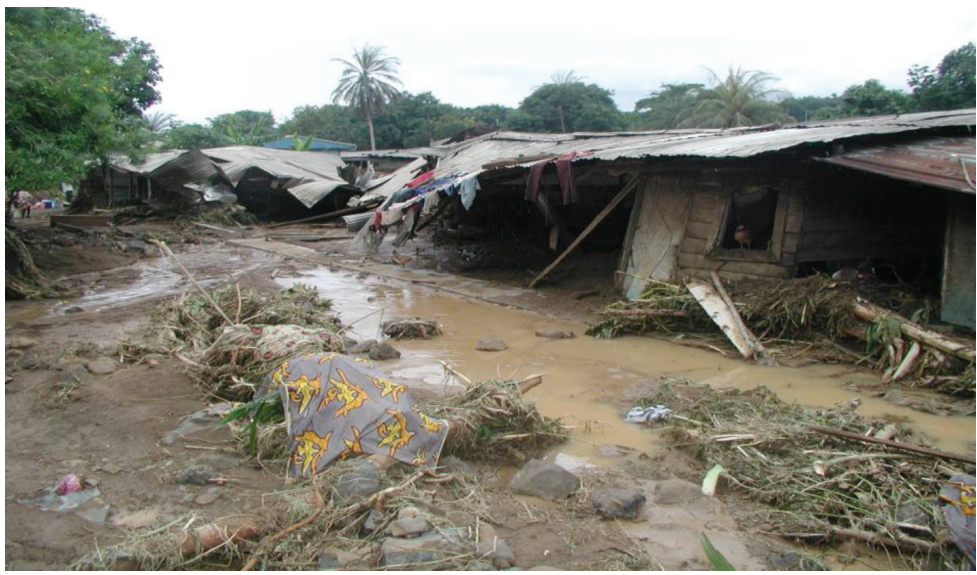

Source: Nsoyunic Lawrence, Date Unknown. 
The outward expansion of the city of Limbe is strongly inhibited by relief, which consist of several hills and mainly volcanic cones with watersheds partially surrounding the low-lying areas. Poorly consolidated scoriaceous materials characterise these cones with poor structural stability, constituting fragile or marginal environment. The lack of solid waste management contributes to the obstruction of drainage system. Uncontrolled disposal of waste, inappropriate drainage system, unforeseen engineering weaknesses and the expansion of settlement into hilly areas contributes to the anthropogenic causes of floods and landslide in this area.

\section{Natural causes}

\section{Seismic activities}

Seismicity around the MC region is monitored by the Unit for Volcanological and Geophysical Research (ARGV) located at Ekona. Local seismicity for the period preceding the 1999 eruption averaged 15 events per month (Aka, 2001). This increased from more than 15 recorded seismic events in March 26th to over 200 seismic events on the 27th and 28 of March 1999. An intensity VI earthquake on March 28th was felt over a $100 \mathrm{~km}$ radius around the mountain and destroyed houses in Buea and environs. This indicated the start of the March 1999 eruption of the volcano. A macro seismic study of the earthquake activity in Limbe showed that it was felt more by people living up slope in the hillside than by those living on the valleys (Aka Fstus, unpublished work). The 2000 eruption was accompanied by much less ground shaking than the 1999 eruption. The monthly local seismicity of the MC region for the period July 2000 - June 2001 is shown in Fig5a. Daily activity for June 2001 is shown in Fig 5b.

The June activity is characteristic of the very regular (9-15 events per month) low magnitude $(2.8 \pm 0.1)$ subcrustal earthquakes of the southeast flank of MC (Ateba and Ntepe, 1997). These are usually not felt even in their epicentral (Tiko) region. Judging from the lack of increased seismicity before and/or on the 27th of June 2001, it does not seem that an earth tremor was a major triggering mechanism for the June 2001 landslide. This is supported by field evidence that people in Limbe never fell any earthquakes before the disasters. However, seismicity probably played an indirect role in that the widespread and intense pre-1999 eruption shaking perhaps exacerbated the opening up of cracks in the hills around Limbe, which would have facilitated the infiltration rate of rainwater.

\section{Rainfall}

Rainfall data for the past 11-27 years were compiled for four Cameroon Development Corporation (CDC)-run meteorological stations in and around Limbe. 
Fig. $5 a$ and b. Seismicity of the Mount Cameroon region showing (a) total seismicity for the year 2000/2001 and (b) daily seismicity for June 2001. Data source: Aka Festus, Institute for Mining and Geological Research, Ekona
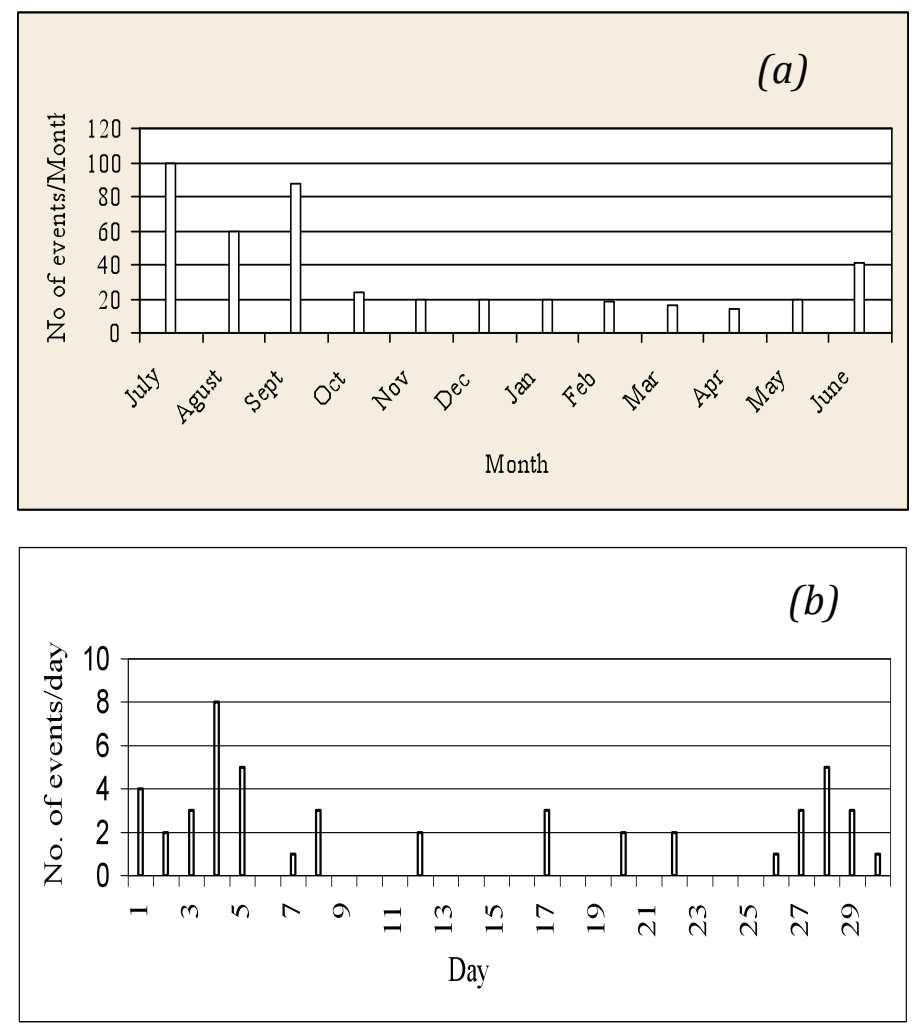

Source: Aka, 2001

A histogram (not shown) for the mean annual rainfall for these stations shows a monotonous decrease from Mabeta Bimbia to Benoe Esuke located further inland. This can be explained by the role of $\mathrm{MC}$ that acts as a barrier to moist westerly winds from the Atlantic Ocean, such that rainfall stations located inland record less rain than those close to the ocean (land mass effect). This is why the west coast of Limbe is the wettest places in the world with Debuncha in the west coast having 10,000 mm of rainfall/yr. Like wise, villages on the (leeward) northeastern side of the volcano like Mpundu and Muyuka are located in the rain shadow and have mean annual rainfall of 2000-2250mm. Mean monthly rainfall for these stations is plotted on Figure $5 \mathrm{a}$ and $\mathrm{b}$ and shows that rainfall occurs almost entirely in the 'rainy season' in other words, April to September, with a peak in July, the highest monthly rainfall. 
Fig.6 (a), Mean yearly rainfall for 4 stations around Limbe from 1971 to 2001 (b) daily rainfall for the month of June 2001 at Bota Head Office and (c)at Mabeta Bimbia Data sources, CDC-run metrological stations
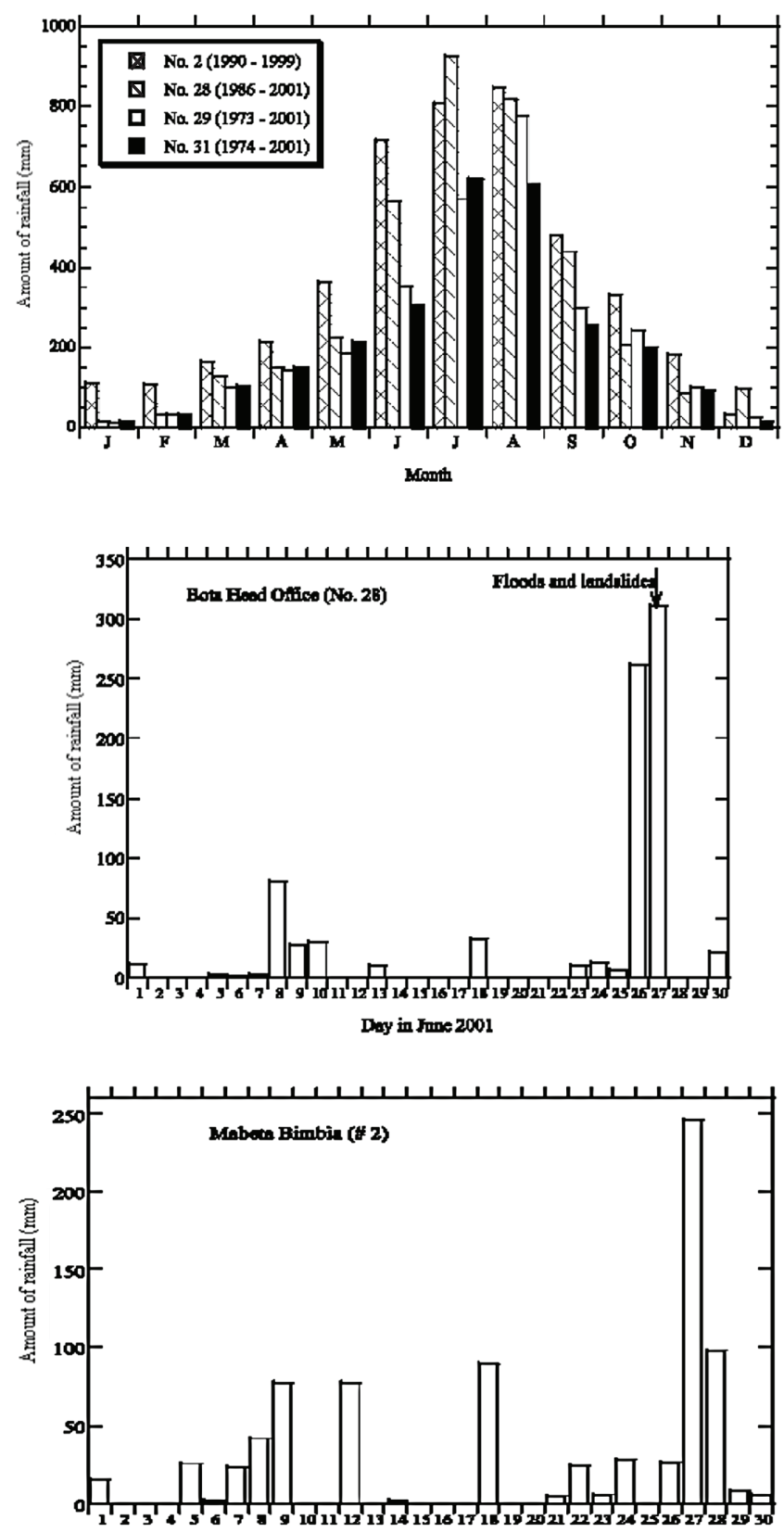

Source: CDC-run meteorological stations

Dev in Jum 2001 
Recorded in these stations so far is $1705 \mathrm{~mm}$ in July 1993 at the Bota Head Office. Daily rainfall data for June 2001 is shown for Bota Head Office (Fig. 6b) and Mabeta Bimbia (Fig. 6c). Using this data, a rainfall intensity of $1.1 \mathrm{~mm} / \mathrm{hr}$ is estimated. This is between 10\% (Mabeta Bimbia) and 45\% (Bota Head Office) higher than 15-year mean annual rainfall intensity for these stations. Much of the June 2001 rainfall occurred within a very short time.

Questionnaire accounts indicate that very heavy rains started in Limbe at about 5:00 pm local time on June 26th and continued unabated till about $1.00 \mathrm{pm}$ on the 27 th when the landslides and floods occurred. This is confirmed by the daily June rainfall data (Figs. $6 \mathrm{~b}$ and c). Of the total June rainfall recorded at the Bota Head Office station, $70 \%$ of it occurred on the 26 th and 27 th alone. This was mostly concentrated within about $20 \mathrm{hrs}$ (5pm 26th - 1pm 27th) as suggested by field reports.

This is evidence for the occurrence of a rainstorm (prolonged rainfall over days or, as in this case, unusually intense over a short period) during these two days and suggests that rainstorm likely contribute greatly to both landslide and floods in this region over the years. This conclusion finds support in the observation that all recorded landslides in Cameroon within the last 18 years (Table 1) have occurred between the months of June and September which are the rainiest months of the year in Cameroon.

\section{Conclusion}

Considering landslide and flood risk zones in the Limbe subdivision, it is evidenced that most affected areas by landslides are build up areas on hilly sites of steep slopes. The level of disturbance of this zones resulting from not respecting slope gradient during excavation increases the level of landslide hazards. Flooding affected populations are those living within a buffer zone of less than a $100 \mathrm{~m}$ from both river Djenguele and Limbe river. Dumping of waste into these rivers and the low nature bridges blocks water from free-flowing. Moreover, increase intensity of rainfall over the years during some months has contributed to the frequent flooding recorded in this region. While some work is already ongoing, the Limbe municipality could assist toward intensification in the planting of more deep-rooted trees along the hill sites. River channels should be cleared during the last months of the year prior to the beginning of the raining seasons to ensure free water passage. 


\section{Recommendations}

Given the potential for population expansion in the subdivision and especially within the city of Limbe and the eventual need for more settlement land, the following measures are recommended which might likely mitigate future landslides and floods in the subdivision.

(1) People should not necessarily be moved away or stopped from building on habitable areas of the 'hazard' zone, which has been a common approach by government, because this might only be an ineffective and short-term measure. An important proportion of Limbe subdivision is hilly with remarkable lowlands but fortunately most of the hills at the foot and slopes of which people have dug and put up houses only rise to a high of $-350 \mathrm{~m}$ altitude. Landslide mitigation measures like excavation (Rogers, 1992) and planting of soil-reinforcement plants can take advantage of the low-altitude hills and increase well planned development in these hillside areas.

(2) A detailed hydrologic monitoring study of Djenguele River should be undertaken to know the flow rate and volume of water discharged both at high (rainy season) and at low (dry season) peaks. This will provide indispensable data for the canalization of the river from its upper tributaries through its whole course along the city of Limbe down to the sea.

(3) A stricter building code should be implemented that amongst other things, prohibits people from building at unsafe distances from the river channel and from disposing of domestic sewage into the river. The local authority also should consider mainstreaming disaster risk into developmental plans as in shrine in Hyogo Framework for Action for disaster risk reduction in the world (Hyogo Framework for Action 2005-2015).

(4)Population living along the frequently flooded inundated rivers should be advice to increase foundations of houses in this area to avoid future incidences from excessive impact.

(5) An improved drainage system and monitoring of water level and quantity/ quality of water in hand-dug wells in the city of Limbe will enhance an appraisal of the volumes and impact of septic waste and rainfall water contribution to the groundwater budget. 
(6) Before the above measures are taken, people living on and at the foot of steep hills should quit their houses when rainfall is heavy and continuous until the rainfall intensity reduces

(7) There is a need for a national Vulnerability Assessment with the objective to:

- To provide geospatial data to decision-makers on the nature of vulnerability of the population and the overall state of preparedness at the national, local and community levels.

- To serve as a basis of starting point of the national disaster management planning.

- To serve as a basis for a continuous monitoring of trends in physical, social, economic and infrastructures conditions in high risk and disaster prone areas.

\section{Acknowledgment}

I extend special gratitude to ProVention Consortium's action and research grant programme for providing me with the opportunity to undertake this research work. Special thanks also go to my mentors - Dr Aka Festus and Dr Christopher Agingy for their valuable assistance and guidance during the project period. UNEDRA further played an important role in my exposure to international training related to disaster risk.

\section{References}

AGINGY, C. 2005. (Department of Geology and Environmental Sciences, University of Buea,Cameroon)-personal communication,

AKA F. 2001. (Institute for Geological and Mining Research-Ekona) Landslide swam in Limbe (unpublished work).

ATEBA, B. and NTEPE, N. 1997. Post-eruptive seismicity of Mount Cameroon (Cameroon), West Africa: a statistical analysis. J. Volcanol. Geotherm. Research. 79, 25-45.

AYONGHE, S.N., MAFANY, G.T., NTASIN, E., SAMALANG, P. 1999. Seismically activated swarm of landslides, tension cracks and rockfall after heavy rainfall in Bafaka, Cameroon. Natural hazards, 19, 13-27.

ESPIZUA, L.E. and BENGOCHEA, J.D. 2002. Landslide hazard and risk zonation mapping in the Río Grand Basin, Central Andes of Mendoza, Argentina. Mountain Research Development. 22, 177-185.

KETTRIDGE, J. O., ed. 1980. Dictionary of Technical Terms and Phrases. “Scoriaceous”. London: Routledge \& Kegan Paul. 453p. 
KUSAKABE, M., OHSUMI, T., ARAMAKI, S. 1989. The Lake Nyos Gas Disaster: Chemical and isotopic evidence in waters and dissolved gases from three Cameroonian crater lakes, Nyos, Monoun and Wum. In: Le Guern F. and Sigvaldason G. (eds) The Lake Nyos Event and Natural CO2 Degassing I. J. Volcanol. Geotherm. Res. 39, 167-185

NEBA, A. 1999. Modern Geography of the Republic of Cameroon. Bamenda: Neba Publishers. 3rd Edition.

NGWA, C.N., AYONGHE, S.N., UBANGOH, R.U. 2001. An evaluation of risk zones around Mount Cameroon based on studies of macroseismicity and volcanic eruptions linked to its March - April 1999 eruption. Journal of Cameron. Geoscience. Society. 1, 94-95.

NKOUMBOU, C., DeRUElle, B., VEldE, D. 1995. Petrology of Mt. Etinde Nephelinite Series. J. Petrol. 36, 373-395.

ROGERS, W.P., ENGLISH, D., SCHUSTER, R.L., AND KIRKHAM, R.M. 1992. Large rock Slide/debris avalanche in the San Juan Mountains, southwestern Colorado, USA, July 1991: Landslide News, no. 6, p. 22-24.

SIGURDSSON H, HOUGHTON BF, MCNUTT S, RYMER H, STIX J 1987, Encyclopaedia of volcanoes. Academic, San Diego, pp 915-930

SUH, E.C., SPARKS, R.S.J., FITTON, J.G., AYONGHE, S.N., ANNEN, C., NANA, R., LUCKMAN, A. 2003. The 1999 and 2000 eruptions of Mount Cameroon: eruption behaviour and petro-chemistry of lava. Bull. Volcanol. 65, 267-281.

TCHOUA, F.M., WANDJI, P., NANA, R., KAMGANG, P. TEITCHOU, I. 2001. Les eruption historiques du Mont Cameroun et leur impact sur Buea et sa region. J. Cameroun. Géosciences. Soc. 1, 127-128.

WORLD CONFERENCE ON DISASTER REDUCTION. 2005. Hyogo framework of action 2005-2015. Building the resilience of nations and communities to disasters. Pp $1-22$.

ZOGNING, A. 2001. La Catastrophe du 21 Juin 2001 à Limbé. Rapport Scientifique MINREST/INC/DRG.13p.

\section{Endnotes}

I. A $1600 \mathrm{~km}$ long chain of Cenozoic-Present volcanoes that traverses the country in a SW-NE direction from the Gulf of Guinea island of Annobon across Cameroon to eastern Nigeria (Fitto 1979 in Tchoua FM, Wandji P, Nana R, Kamgang P, Teitchou I, 2001).

II. Computer based Visual interpretation of satellite image showing areas with previous landslide and areas with very steep slopes which are potential landslide zones.

III. Volcanic slag (Kettridge, 1980: 453) 